\title{
Article \\ Kidney Transplantation for Focal Segmental Glomerulosclerosis: Can We Prevent Its Recurrence? Personal Experience and Literature Review
}

\author{
Hamza Naciri Bennani ${ }^{1, \dagger}$, Lionel Elimby ${ }^{1,+}$, Florian Terrec ${ }^{1}\left(\mathbb{D}\right.$, Paolo Malvezzi ${ }^{1}$, Johan Noble ${ }^{1}(\mathbb{D}$, \\ Thomas Jouve ${ }^{1,2} \mathbb{D}$ and Lionel Rostaing $1,2, * \mathbb{D}$ \\ 1 Nephrology, Hemodialysis, Apheresis and Kidney Transplantation Department, Grenoble University \\ Hospital, 38000 Grenoble, France; hnaciribennani@chu-grenoble.fr (H.N.B.); lelimby@chu-grenoble.fr (L.E.); \\ fterrec@chu-grenoble.fr (F.T.); pmalvezzi@chu-grenoble.fr (P.M.); jnoble@chu-grenoble.fr (J.N.); \\ tjouve@chu-grenoble.fr (T.J.) \\ 2 Nephrology Department, Grenoble Alpes University, 38000 Grenoble, France \\ * Correspondence: lrostaing@chu-grenoble.fr; Tel.: +33-4-7676-8945 \\ + These authors contributed equally to this work.
}

check for updates

Citation: Naciri Bennani, H.; Elimby, L.; Terrec, F.; Malvezzi, P.; Noble, J.; Jouve, T.; Rostaing, L. Kidney Transplantation for Focal Segmental Glomerulosclerosis: Can We Prevent Its Recurrence? Personal Experience and Literature Review. J. Clin. Med. 2022, 11, 93. https://doi.org/ $10.3390 /$ jcm 11010093

Academic Editor: Eytan Mor

Received: 24 November 2021 Accepted: 21 December 2021 Published: 24 December 2021

Publisher's Note: MDPI stays neutral with regard to jurisdictional claims in published maps and institutional affiliations.

Copyright: (C) 2021 by the authors. Licensee MDPI, Basel, Switzerland. This article is an open access article distributed under the terms and conditions of the Creative Commons Attribution (CC BY) license (https:// creativecommons.org/licenses/by/ $4.0 /)$.

\begin{abstract}
Background: Primary focal segmental glomerulosclerosis (FSGS) is associated with a high risk of recurrence after kidney transplantation with a major risk of graft loss despite preventive or curative treatments. Aim: to assess graft survival in FSGS kidney-transplant recipients and to compare those that had a relapse with those that had no relapse. Patients/Methods: we included 17 FSGS kidney-transplant recipients between January 2000 and January 2020, separated retrospectively into two groups (recurrences: $n=8$ patients; no recurrences: $n=9$ patients). FSGS recurrence was defined as having proteinuria of $\geq 3 \mathrm{~g} / \mathrm{g}$ or urinary creatinine of $\geq 3 \mathrm{~g} /$ day. All patients received an induction therapy; maintenance immunosuppressive therapy at post-transplantation relied on tacrolimus/mycophenolate mofetil/steroids. In order to prevent or treat FSGS recurrence, patients received apheresis sessions plus rituximab. Results: FSGS recurrence rate was $47 \%$. All patients that relapsed with a first graft also relapsed with subsequent grafts. Median time to recurrence was 3 (min: 1; max: 4745) days, despite rituximab/apheresis prophylaxis. Mean age was significantly lower in the relapsers (group 1) than in the non-relapsers (group 2); i.e., $47 \pm 11$ vs. $58 \pm 9$ years $(p=0.04$ ). Time to progression to stage 5 chronic kidney disease (CKD) and young age at FSGS diagnosis were lower in group 1 compared to group 2; i.e., 5 (min: 1 ; max: 26) vs. 2 ( $\min : 1$; max: 26) years, and 16 (min: 4; max: 55) vs. 34 (min: 6; $\max 48$ ) years, respectively. There was no difference between the two groups in terms of progression to CKD stage 5 on the native kidneys, averaging 7 years in both groups $(p=0.99)$. In group 1 , seven patients received rituximab/apheresis prophylaxis, although this did not prevent the recurrence of FSGS. Conclusion: pretransplant prophylaxis with plasmapheresis/rituximab did not appear to reduce the risk of recurrence of primary FSGS on the graft, but could allow remission in the event of recurrence.
\end{abstract}

Keywords: plasmapheresis; rituximab; focal segmental glomerulosclerosis; recurrence; kidney transplantation; immunoadsorption

\section{Introduction}

Primary focal segmental glomerulosclerosis (FSGS) is a diagnosis of exclusion, because the histological lesion does not allow guiding the pathogenesis. It is a glomerular lesion characterized by the presence of sclerotic and hyaline lesions, which may be associated with deposits of immunoglobulin $\mathrm{M}(\mathrm{Ig} \mathrm{M})$ and the C3 complement fraction [1]. The incidence of primary FSGS has increased, and accounts for 20-25\% of adult patients undergoing biopsy for evaluation of idiopathic GN [2-4]. It is manifested by nephrotic proteinuria $>3 \mathrm{~g} /$ day in more than $70 \%$ of cases, often relatively sudden. Hypertension, microscopic hematuria, and renal insufficiency are seen in $30-45 \%$ of cases at presentation [3]. 
Whether primary, secondary, or genetic, FSGS progresses to chronic kidney disease (CKD); kidney transplantation is then the treatment of choice in stage 5 CKD. Primary FSGS is associated with a high risk of recurrence in a graft after kidney transplantation, reaching $30 \%$ after a first transplant and $80-100 \%$ after a second kidney transplant [5]. The precise identification of patients at risk for recurrence of primary FSGS on the graft is crucial in order to choose which type of graft to offer. Despite the significant risk of recurrence, patients with primary FSGS are often candidates for kidney transplantation. Indeed, their young age makes it difficult to contraindicate transplantation, even if it is a second or even a third transplant attempt.

Recurrence on the graft is defined by the reappearance of glomerular-type proteinuria, with or without nephrotic syndrome, and the absence of other causes that may be the origin of this proteinuria. It usually occurs very quickly, within hours or days after kidney transplantation [6]. The pathophysiology of the recurrence of primary FSGS is unknown, and the existence of a circulating factor (suPAR, CASK, anti-actin antibody, CD40) can attack podocytes quickly after unclamping [4,7-14]. Plasma exchange could eliminate this circulating permeability factor, allowing remission in more than $50 \%$ of cases [15]. In the event of recurrence, the risk of graft loss is major, and preventive or curative treatment for recurrence combines sessions of apheresis with immunosuppression (i.e., corticosteroids, calcineurin inhibitors, rituximab) without evidence-based medicine. Our single-center study aimed to assess graft survival in kidney-transplant recipients according to whether there was an FSGS relapse, and to compare characteristics of those that had a relapse with those that did not. We also performed a literature review on FSGS recurrence after kidney transplantation and its prevention.

\section{Materials and Methods}

\subsection{Study Population}

This single-center retrospective study included 17 kidney-transplant recipients with primary FSGS that attended our hospital between January 2000 and January 2020.

Diagnosis of primary FSGS was retained after kidney biopsy and in absence of other etiologies. Only a single patient whose diagnosis of FSGS was made at the age of 4 years was able to benefit from the genetic study, which came back negative.

FSGS recurrence was defined as having proteinuria of $\geq 3 \mathrm{~g} / \mathrm{g}$ or urinary creatinine of $\geq 3 \mathrm{~g} /$ day, whatever the time of onset after transplantation. It was mandatory to eliminate other causes of early de novo proteinuria, including acute humoral rejection (donor-specific antibodies, increased serum creatinine, decreased diuresis). Kidney graft biopsy was not systematic; i.e., it was only performed when recurrence occurred late after transplantation or in the event of presence of a donor-specific alloantibody (or alloantibodies).

The time to recurrence was defined according to Cameron's classification [16]: immediate $(<48 \mathrm{~h}$ ), early ( $<3$ months), or late recurrence ( $>3$ months).

Complete remission was defined as having proteinuria $<0.5 \mathrm{~g} /$ day for at least 2 consecutive weeks. Partial remission was defined as a reduction in proteinuria to $0.5-3 \mathrm{~g} /$ day or having decreased proteinuria of $>50 \%$ from the baseline value for at least 2 consecutive weeks.

The main objective was to assess the survival of the renal transplant according to FSGS relapse, which was then treated by apheresis and/or rituximab.

All patients received an induction therapy before transplantation of either antithymocyte globulins or basiliximab. Maintenance immunosuppressive therapy at posttransplantation relied on tacrolimus (aiming at trough levels of $5-8 \mathrm{ng} / \mathrm{mL}$ ), mycophenolate mofetil ( $1 \mathrm{~g} /$ day), and steroids (prednisone). 


\subsection{Preventing Recurrence of FSGS}

\subsubsection{Apheresis}

In order to prevent recurrence of FSGS, patients received one plasma exchange before transplantation, and then three plasma exchanges per week during the first 2 weeks posttransplantation. It was only performed in 7 patients due to a recurrence on a previous kidney graft.

However, in the event of an FSGS relapse immediate or early after transplantation the previous schedule was modified accordingly; i.e., apheresis sessions were intensified. Plasma exchanges were carried out by centrifugation using Comtec ${ }^{\circledR}$ (Fresenius Kabi, Louviers, France) or Spectra Optia ${ }^{\circledR}$ (BCT Terumo, Lakewood, CO, USA) separators. The plasma volume was treated as 1.5 times the plasma volume calculated using Kaplan's formula [17]: $\mathrm{PV}=0.065 \times$ weight $(\mathrm{kg}) \times(1$ - hematocrit $)$. The replacement fluid used was $4 \%$ albumin except in the immediate pre- and post-transplantation sessions, when fresh frozen plasma was used as the replacement fluid. Extracorporeal anticoagulation was based on regional anticoagulation using citrate with reinjection of calcium into the return venous line according to ionized calcium levels, which were maintained at $1.15-1.35 \mathrm{mmol} / \mathrm{L}$.

After January 2016, patients that experienced a post-transplantation FSGS relapse had plasma exchanges replaced with immunoadsorption. Two Globaffin ${ }^{\circledR}$ columns (Fresenius Medical Care, Bad-Homburg, Germany) were used alternately for every $500 \mathrm{~mL}$ of treated plasma (i.e., one was rinsed while the other filtered the plasma). The Globaffin ${ }^{\circledR}$ adsorber used synthetic peptide GAM ligands that bind the constant $(\mathrm{Fc})$ portion of the immunoglobulins, particularly the Ig G1, 2, and 4 subclasses. The volume of treated plasma per session was $100 \mathrm{~mL} \times$ body weight $(\mathrm{kg})$.

In group 1, one patient received pretransplant immunoadsorption sessions in preparation for an incompatible HLA kidney transplantation, and another patient received eight plasma-exchange sessions after transplantation to avoid a relapse of FSGS upon request of his nephrologist.

\subsubsection{Rituximab}

Rituximab was used to prevent and treat the recurrence of FSGS at a dose of $375 \mathrm{mg} / \mathrm{m}^{2}$, given as one or two injections at one week apart. In the prophylactic setting, rituximab was given in a single dose. In curative treatment, rituximab was administered twice 2 weeks apart, then every 6 months depending on the clinical-biological evolution (nephrotic syndrome, serum albumin, proteinuria).

When combined with apheresis, rituximab was always given after an apheresis session.

The next post-rituximab apheresis session was performed $72 \mathrm{~h}$ after the rituximab injection to minimize drug elimination during apheresis.

Rituximab was administered as a pretransplant in 7 patients in group 1 due to recurrence of FSGS on a previous kidney graft, and in a single patient in group 2 in the setting of an incompatible HLA kidney with specific donor antibodies.

\subsection{Treating FSGS Recurrence}

Treatment of FSGS consisted of intensified plasma exchange or IA sessions: i.e., every other day for 2 weeks, and was then adapted to proteinuria level. Patients also received either methyl-prednisone pulses $(10 \mathrm{mg} / \mathrm{kg}$ for three consecutive days) or prednisone, which was increased at $1 \mathrm{mg} / \mathrm{kg} /$ day for 3 weeks and then slowly tapered. Rituximab was also given $\left(375 \mathrm{mg} / \mathrm{m}^{2}\right.$ of body surface area) at the 4 th and 8 th apheresis sessions.

\subsection{Collected Data}

The data collected included age, body mass index (BMI), and gender. Before kidney transplantation, we determined age at diagnosis of FSGS, time to progression to CKD stage 5, previous renal transplants (dates, number, causes of graft loss), time on dialysis before transplantation (in months), magnitude of anti-HLA sensitization, and blood group. After kidney transplantation, we collected characteristics on the donor-recipient pair (HLA 
matching, cytomegalovirus-CMV-serostatus), time to recurrence of FSGS, induction and maintenance immunosuppressive treatments, and the use of renin-angiotensin system blockers. In addition, at regular intervals post-transplantation, we collected the following data: serum creatinine, estimated glomerular-filtration rate (GFR) ( $\left.\mathrm{mL} / \mathrm{min} / 1.73 \mathrm{~m}^{2}\right)$, albuminemia, serum protein, proteinuria, IgG, IgA and IgM, renal-allograft histology, infectious complications (bacterial or viral; i.e., CMV, BK virus, Epstein-Barr virus, and DNAemia).

The study was conducted according to the guidelines of the Declaration of Helsinki and approved by CNIL (French national commission for data protection; approval number 1987785v0). The biobank collection number is BRIF BB-0033-00069.

All data are available upon request to the corresponding author.

\subsection{Statistical Analyses}

Quantitative data are presented as means \pm standard deviations (SD) or medians and quartiles (Q1-Q3). Qualitative data are presented as absolute numbers with percentages. Differences were calculated using the chi-squared or Fisher's exact test for categorical data, Student's test and ANOVA were used for normally distributed numeric data variables, and the Mann-Whitney-U and Kruskal-Wallis tests for non-Gaussian variables.

A two-sided $p$-value of $<0.05$ was considered statistically significant. Analyses were conducted using R statistical software (version 4.1.2, Bell Laboratories, Holmdel, NJ, USA).

\section{Results}

\subsection{Study Population}

We retrospectively separated the patients into two groups according to whether or not they had FSGS recurrence; i.e., FSGS recurrence (group 1: 8 patients), and no FSGS recurrence (group 2: 9 patients). Of the eight kidney-transplant recipients that had FSGS relapse, $75 \%$ had an early relapse. Median time to recurrence was 3 (min: 1; max: 4745) days. The mean age was significantly lower in group 1 than in group 2; i.e., $47 \pm 11$ years vs. $58 \pm 9$ years $(p=0.04)$. The age at diagnosis of FSGS was also lower in group 1 than in group 2; i.e., 16 (min: 4; max: 55) vs. 34 (min: 6; max: 48) years $(p=0.12)$. There was no difference between the two groups in terms of progression to CKD 5 on the native kidney, averaging 7 years in both groups $(p=0.99)$. The patients' demographic criteria are listed in Tables 1 and 2 .

Table 1. Demographic data from the study population.

\begin{tabular}{|c|c|c|c|c|}
\hline & Patients $(n=17)$ & $\begin{array}{l}\text { FSGS Recurrence: Group } \\
\qquad(n=8)\end{array}$ & $\begin{array}{c}\text { No Recurrence: Group } \\
2(n=9)\end{array}$ & $p$-Value \\
\hline Age (years) & $53 \pm 11$ & $47 \pm 11$ & $58 \pm 9$ & 0.04 \\
\hline Gender $(\mathrm{M} / \mathrm{F})$ & $8 / 9$ & $4 / 4$ & $4 / 5$ & 0.81 \\
\hline Age at FSGS diagnosis (years, min-max) & $25(4-55)$ & $16(4-55)$ & $34(6-48)$ & 0.12 \\
\hline $\begin{array}{l}\text { Time to progression to CKD5 } \\
\text { (years, min-max) }\end{array}$ & $5(1-26)$ & $2(1-26)$ & $6(1-22)$ & 0.99 \\
\hline $\begin{array}{l}\text { Time to post-transplant recurrence } \\
\text { (days, min-max) }\end{array}$ & $3(1-4745)$ & $3(1-4745)$ & NA & \\
\hline Number of kidney transplants & $1(1-3)$ & $2(1-3)$ & $1(1-3)$ & 0.13 \\
\hline \multicolumn{5}{|l|}{ Type of donor: } \\
\hline $\begin{array}{ll}\text { - } & \text { Brain death } \\
\text { - } & \text { Cardiac death } \\
\text { - } & \text { Living donor }\end{array}$ & $\begin{array}{c}11 \\
4 \\
2\end{array}$ & $\begin{array}{l}6 \\
0 \\
2\end{array}$ & $\begin{array}{l}5 \\
4 \\
0\end{array}$ & 0.109 \\
\hline Proteinuria at recurrence $(\mathrm{g} / \mathrm{L})$ & $4.9 \pm 3.6$ & $4.9 \pm 3.6$ & & \\
\hline
\end{tabular}


Table 1. Cont.

\begin{tabular}{cccc}
\hline & Patients $(\boldsymbol{n}=\mathbf{1 7})$ & $\begin{array}{c}\text { FSGS Recurrence: Group } \\
\mathbf{1}(\boldsymbol{n}=\mathbf{8})\end{array}$ & $\begin{array}{c}\text { No Recurrence: Group } \\
\mathbf{2}(\boldsymbol{n}=\mathbf{9})\end{array}$ \\
\hline Serum protein at recurrence $(\mathrm{g} / \mathrm{L})$ & $61 \pm 10$ & $61 \pm 10$ & \\
\hline Serum creatinine at recurrence $(\mu \mathrm{mol} / \mathrm{L})$ & $354 \pm 235$ & $354 \pm 235$ & \\
\hline eGFR at recurrence $\left(\mathrm{mL} / \mathrm{min} / 1.73 \mathrm{~m}^{2}\right)$ & $20(4-77)$ & $20(4-77)$ & 1 \\
\hline Rituximab pre-renal transplant & 8 & 7 & 0 \\
\hline Rituximab post-renal transplant & 8 & 8 & 0 \\
\hline Number of rituximab doses at post-renal \\
transplant
\end{tabular}

Abbreviations: PE, plasma exchange; IA, immunoadsorption; M, male; F, female; eGFR, estimated glomerularfiltration rate; NA, not applicable; NS, nonsignificant; AT1RB, angiotensin-II type 1 receptor blocker.

Table 2. Characteristics of patients.

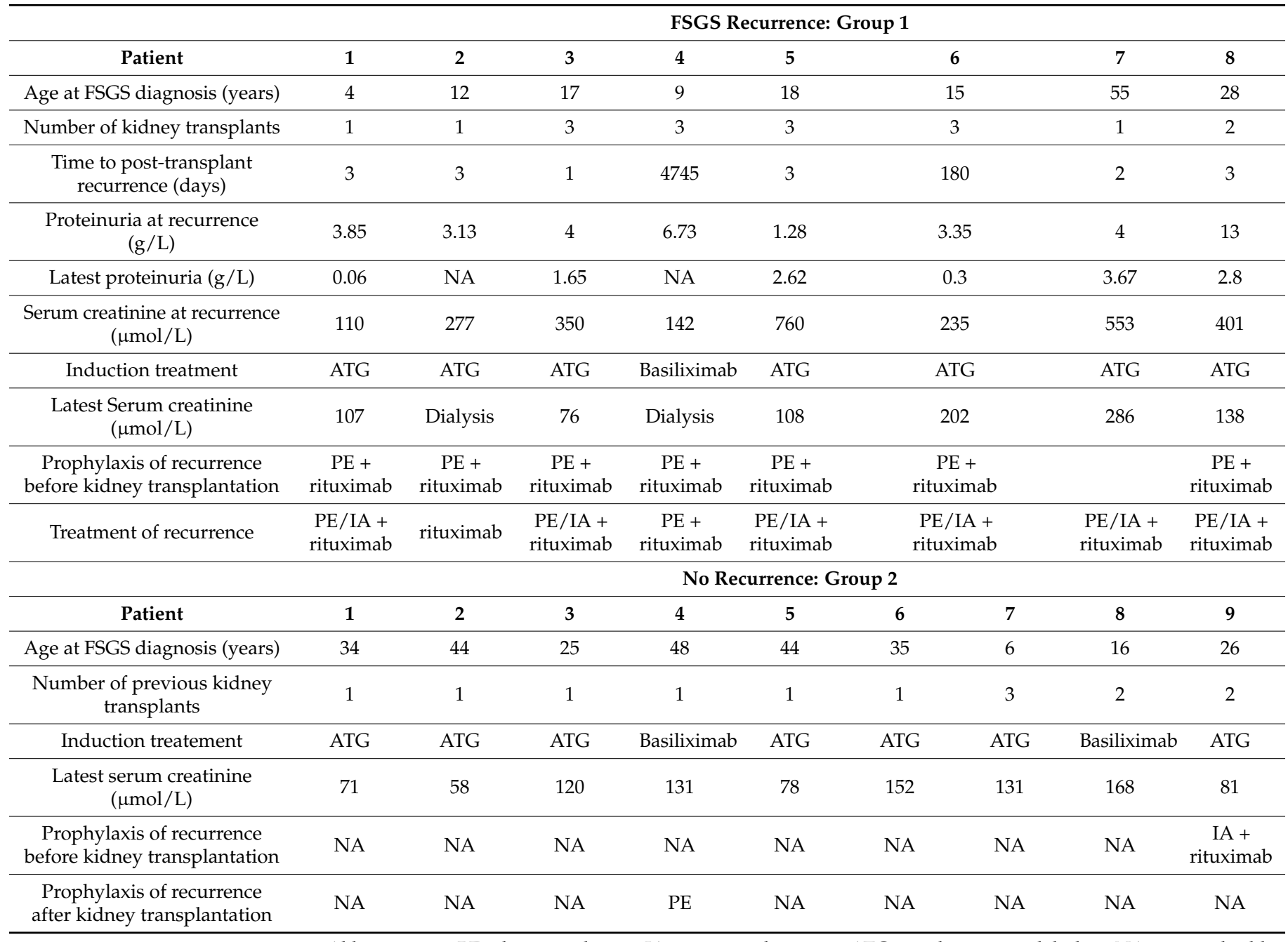

Abbreviations: PE, plasma exchange; IA, immunoadsorption; ATG, antithymocyte globulins; NA, not applicable. 
Overall, the rate of recurrence of primary FSGS on the kidney transplant was $47 \%$. In addition, all patients that relapsed after a first graft also relapsed with subsequent grafts.

In group 1, four patients had undergone three kidney-transplant procedures, three patients had received a single kidney transplant, and one patient had undergone two kidney-transplant procedures. All group 1 patients had a FSGS relapse that resulted in loss of the previous renal graft. Taking into account only the most recent renal transplant, seven patients received prophylaxis with rituximab and apheresis at the time of surgery, although this did not prevent the recurrence of FSGS on the renal graft. In addition, in the posttransplantation setting, eight patients received rituximab: of these, seven also had apheresis sessions. After an average follow-up of $7 \pm 3$ years, there were two renal-graft losses with a return to dialysis, two patients remained dependent on immunoadsorption at a rate of one session every 4 weeks, and four patients were in clinical remission after treatment with apheresis and rituximab after recurrence of FSGS without immunoadsorption. The average current eGFR for group 1 patients was $59 \pm 33 \mathrm{~mL} / \mathrm{min}$.

In group 2, six patients underwent one kidney transplantation, one patient had three kidney-transplant procedures, and two patients underwent two kidney-transplant procedures. The loss of previous grafts was not related to the recurrence of FSGS: graft-artery thrombosis occurred in one case, and chronic humoral rejection in the other patients. The average duration of follow-up was $7 \pm 4$ years. One patient received eight plasma-exchange sessions after transplantation to avoid a relapse of FSGS at request of his nephrologist, and another patient received 24 IA sessions associated with two infusions of rituximab at pretransplant in preparation for HLA-incompatible kidney transplantation, most likely also eliminating any factor responsible for FSGS. The current average eGFR for all group 2 patients was $65 \pm 25 \mathrm{~mL} / \mathrm{min}$. All patients had nondetectable proteinuria. No patient lost their graft.

Patients from both groups had immediate resumption of graft function; i.e., no patient received immediate postoperative dialysis. No patients presented with any complications related to apheresis (hemodynamic tolerance, hypo- or hypercalcemia). No patient had donor-specific antibodies at the time of the transplantation.

\subsection{Infectious Complications}

In group 1, CMV DNAemia was assessed weekly for the first month, and then before each apheresis session during the maintenance period. In group 2, CMV DNAemia was assessed every 2 weeks for the first 6 months post-transplantation. All the patients except those that were donor CMV seronegative/recipient seropositive underwent CMV prophylaxis for the first three months post-transplant with valganciclovir adapted to eGFR.

If CMV, DNA level was > 3 log copies $/ \mathrm{mL}$, treatment with valganciclovir was initiated (900 $\mathrm{mg} \times 2$ /day) for 3 weeks and adapted to GFR. Overall, only four patients (all from group 1) presented with mild CMV reactivation.

\section{Discussion}

The rate of recurrence of primary FSGS on a renal graft was 20 to $40 \%$ for a first graft, but reached 80 to $100 \%$ recurrence on subsequent grafts if there was recurrence on the first graft $[5,18]$. In our case series, the rate of recurrence of primary FSGS on the kidney transplant was 47\%. Kalliopi Vallianou et al. [19] also found 54\% recurrence of primary FSGS (25 patients) among 46 kidney-transplant recipients; in addition, recurrence developed very soon after transplantation; i.e., the median recurrence time was 0.5 months (0.1-1). The main risk factors for FSGS recurrence were recurrence on a previous transplant, rapid progression to stage 5 CKD on native kidneys, and young age at the time of initial diagnosis [5,20-22]. An albuminemia level of $<25 \mathrm{~g} / \mathrm{L}$ at the time of diagnosis was also considered to be a risk factor for recurrence on the renal transplant [23]. In contrast, the type of donor (living vs. deceased) did not influence the risk of FSGS recurrence [19]. 
In our study, all patients that relapsed with a first graft also relapsed with subsequent grafts. The time to progression to stage 5 CKD and young age at diagnosis of FSGS were lower in the relapsers (group 1) compared to the non-relapsers (group 2); i.e., 5 (min: 1; max: 26) vs. 2 (min: 1; max: 26) years, and 16 (min: 4; max: 55) vs. 34 (min: 6; max: 48) years, respectively. Two of our patients received transplants from living donors.

Despite rituximab and apheresis prophylaxis, group 1 patients had FSGS recurrence after a median of 3 (min: 1; max: 4745) days, and two subsequently lost their allograft. In general, renal transplantation from a living donor allowed better graft survival compared to transplantation from a deceased donor. However, in view of the significant risk of recurrence of primary FSGS, it was not advisable to propose a kidney transplant from a living donor in the event of primary FSGS, especially if there had been recurrence on a previous graft because, to date, there is still no effective prophylaxis that can prevent FSGS recurrence [24,25].

In group 2, no patient had FSGS recurrence in the kidney transplant. The mean age in this group at FSGS diagnosis was 34 (min: 6; max: 48) years. The genetic study was not carried out in these patients. We did not find any secondary causes of FSGS, but we therefore could not rule out a genetic cause explaining absence of FSGS recurrence. Morello et al. [26], in a study published on 101 kidney transplant patients for steroid-resistant nephrotic syndrome (SRNS), after a median follow-up of 58.5 months, found a SRNS recurrence in the first renal transplant in $53.3 \%$ of patients with a nongenetic cause, and in none in those who had a genetic SRNS. They concluded that absence of a causative mutation represented the major risk factor for post-transplant recurrence in children with SRNS.

In our series, prophylaxis with rituximab and apheresis did not appear to reduce the risk of recurrence of primary FSGS. In fact, the combination of plasmapheresis and rituximab immediately before kidney transplantation in $87.5 \%$ of these patients did not prevent recurrence. However, after an average follow-up of $7 \pm 3$ years, this association of treatments seemed to be effective when recurrence occurred at post-transplantation; i.e., remission was induced in $50 \%$ of cases.

Prophylaxis is based on the assumption of the existence of a soluble permeability factor $[4,5]$. This factor has been suggested by several observations, including the development of proteinuria in rats after injection of proteins eluted from an immunoadsorption (IA) column used by FSGS-treated patients [27]. This was also suggested by: (i) the disappearance of nephrotic syndrome after transplantation of a kidney from an FSGS patient into a non-FSGS kidney recipient [7,28,29]; (ii) the occurrence of a nephrotic syndrome in a newborn of an FSGS mother [30]; and (iii) the control of nephrotic syndrome with apheresis [31].

Several factors have been mentioned, such as suPAR, cardiotrophin-like cytokine-1 (CLCF-1), apolipoprotein A1, anti-tyrosine phosphatase antibody of the O receptor, CAsK, and sCD40L [4,8-14], with different mechanisms of action. It seems obvious that the pathophysiology of FSGS is multifactorial. In order to prevent recurrence of FSGS on the kidney transplant, rituximab and apheresis (IA and plasma exchange (PLEX)) are the most frequent treatment used. Apheresis would make it possible to eliminate the soluble hyperpermeability factor, whereas rituximab (anti-CD20 monoclonal antibody) would have two mechanisms of action: (i) depletion of B lymphocytes and facilitating the production of regulatory $\mathrm{T}$ cells, thereby influencing the production of circulating factor; and (ii) inhibition of the degradation of actin in podocytes [32,33] by regulating the activity of acid sphingomyelinase using SMPDL-3B (sphingomyelin phosphodiesterase acid-like $3 b)$.

None of the preventive intervention measures showed any benefits in recurrence of primary FSGS after kidney transplantation. However, Kalliopi Vallianou et al. [19] found that $90 \%$ of patients without recurrence had received prophylaxis by plasmapheresis, versus $62 \%$ of recurrent patients $(p=0.029)$. In contrast, Alasfar et al. [24] carried out a retrospective study that included 37 kidney-transplant recipients at high risk of recurrence for FSGS and that had received preventive treatment with PLEX and/or rituximab. A total 
of $23(62 \%)$ of the 37 patients that received preventive treatment developed recurrence, compared to $14(51 \%)$ recurrences in the 27 patients that received no treatment $(p=0.21)$. Likewise, Verghese et al. [25] retrospectively reviewed pediatric patients with FSGS $(n=57)$ and that had received a kidney transplant. They compared two groups (group 1: kidney transplant recipients after 2006 and that had received a PLEX before transplantation $(n=31)$; and group 2: kidney-transplant patients that received a transplant before 2006 and had not received a PLEX $(n=26))$. They found no significant difference in the incidence (27 vs. $26 \%$, $p=1.0)$ or the time until FSGS recurrence $(p=0.22)$ between the two groups.

Table 3 summarizes the main studies published for adults and children regarding prevention of FSGS recurrence after kidney transplantation by apheresis and/or rituximab. These were mainly retrospective studies. We found no prospective randomized studies. The preventive protocol varied from one study to the other. However, apart from the case reports, we noticed that prophylaxis by apheresis and/or rituximab did not prevent FSGS recurrence. Finally, genetic studies were also missing in most of the studies. 
Table 3. Studies evaluating apheresis and anti-CD20 in prevention of FSGS recurrence.

\begin{tabular}{|c|c|c|c|c|c|c|c|c|c|c|}
\hline \multirow{2}{*}{ References } & \multirow{2}{*}{$\begin{array}{l}\text { Types of } \\
\text { Studies }\end{array}$} & \multirow{2}{*}{$\begin{array}{c}\text { Number of } \\
\text { Patients }\end{array}$} & \multirow{2}{*}{ Age at KTx (Years) } & \multicolumn{2}{|c|}{ Preemptive Protocol } & \multirow{2}{*}{ Genetic Testing } & \multirow{2}{*}{$\begin{array}{l}\text { IS (Induction, } \\
\text { Maintenance) }\end{array}$} & \multirow{2}{*}{ Recurrence Rate } & \multirow{2}{*}{ Graft Survival } & \multirow{2}{*}{$\begin{array}{c}\text { Follow-Up Duration } \\
\text { (Months) }\end{array}$} \\
\hline & & & & Apheresis & Anti-CD20 & & & & & \\
\hline Iguchi [34] & $\mathrm{R}$ & 11 & $33(20-43)$ & $\begin{array}{l}3 \text { sessions PE or } \\
\text { DFPP within } \\
3 \text { days before KTx } \\
\text { in } 3 \text { patients }\end{array}$ & No & NA & $\begin{array}{c}\text { ATG } \\
\text { Cs, CsA, AZA }\end{array}$ & $\begin{array}{c}1 / 3 \text { (33\%) vs. } 4 / 8 \\
(50 \%)\end{array}$ & $100 \%$ vs. $50 \%$ & 25 \\
\hline Ohta [35] & $\mathrm{R}$ & 21 & $5.8 \pm 3$ & $\begin{array}{l}\text { 2-3 sessions PE } \\
\text { immediately } \\
\text { before KTx in } 15 \\
\text { patients }\end{array}$ & No & N/A & $\begin{array}{c}\text { Cs, CsA/Tac, } \\
\text { AZA/mizolibine }\end{array}$ & $\begin{array}{c}5 / 15(33.3 \%) \text { vs. } \\
4 / 6(66.7 \%)\end{array}$ & $87 \%$ vs. $60 \%$ & $48(7-127)$ \\
\hline Gohh RY [36] & $\mathrm{P}$ & 10 & $35 \pm 12(9-46)$ & $\begin{array}{l}8 \text { sessions PE over } \\
\text { a 2-week period } \\
\text { before KTx }\end{array}$ & No & $\mathrm{N} / \mathrm{A}$ & $\begin{array}{l}\text { Basiliximab/ATG } \\
\text { Cs, Tac, MMF }\end{array}$ & $\begin{array}{l}\text { Three patients had } \\
\text { recurrence of } \\
\text { proteinuria (4-10 } \\
\mathrm{g} / 24 \mathrm{~h} \text { ) with FSGS } \\
\text { at biopsy }\end{array}$ & $\begin{array}{l}\text { Serum creatinine } \\
111 \pm 55 \mu \mathrm{mol} / \mathrm{L} \\
\text { Two patients with } \\
\text { recurrence lost allograft } \\
\text { function and returned to } \\
\text { dialysis after } 225 \text { and } \\
962 \text { days }\end{array}$ & $25 \pm 10$ \\
\hline $\begin{array}{c}\text { Couloures K } \\
\text { [37] }\end{array}$ & CR & 1 & 18 & $\begin{array}{c}4 \text { sessions PE } \\
\text { every other day } \\
\text { before KTx and } 6 \\
\text { sessions after KTx }\end{array}$ & No & $\begin{array}{l}\text { Genetic testing for } \\
\text { the mutations in } \\
\text { the NPHS2 gene } \\
\text { was negative. }\end{array}$ & $\begin{array}{l}\text { Dacluzimab } \\
\text { Cs, CsA, MMF }\end{array}$ & No & $\begin{array}{l}\text { Serum creatinine } \\
106 \mu \mathrm{mol} / \mathrm{L}\end{array}$ & 18 \\
\hline Fornoni [32] & $\mathrm{R}$ & 41 & $\begin{array}{c}15 \pm \\
5.5 \text { with RTX and } \\
12.3 \pm 5.2 \text { without } \\
\text { RTX }\end{array}$ & No & 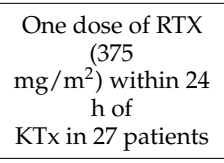 & $\mathrm{N} / \mathrm{A}$ & $\begin{array}{l}\text { ATG/daclizumab/ } \\
\text { alemtuzumab } \\
\text { Cs, Tac, MMF }\end{array}$ & $\begin{array}{c}7 / 27(26 \%) \text { vs. } \\
9 / 14(64 \%)\end{array}$ & $95.8 \%$ vs. $85.7 \%(p=0.26)$ & 12 \\
\hline Gonzalez [38] & $\mathrm{R}$ & 34 & $13 \pm 5$ & $\begin{array}{l}\text { 1-10 sessions PE } \\
\text { before KTx in } 17 \\
\text { patients }\end{array}$ & No & $\begin{array}{l}\text { NPHS2 mutation } \\
\text { testing on } 10 \\
\text { patients ( } 9 \text { tested } \\
\text { negative, } 1 \text { tested } \\
\text { positive) }\end{array}$ & $\begin{array}{c}\text { ATG/daclizumab } \\
\text { Cs, CsA/Tac, } \\
\text { MMF }\end{array}$ & $\begin{array}{l}9 / 17 \text { (53\%) vs. } \\
10 / 17(59 \%)\end{array}$ & $\begin{array}{l}\text { Graft loss: } 25 \% \text { in } \\
\text { recurrence group vs. 20\% } \\
\text { in nonrecurrence group }\end{array}$ & 36 \\
\hline $\begin{array}{c}\text { Chikamoto H } \\
\text { [39] }\end{array}$ & $\mathrm{CR}$ & 1 & 7.5 & $\begin{array}{c}4 \text { sessions } \\
\text { PE from days }-12 \\
\text { to }-5 \text { before KTx }\end{array}$ & $\begin{array}{l}\text { RTX } 21 \text { days } \\
\text { before the KTx }\end{array}$ & $\begin{array}{l}\text { Genetic testing for } \\
\text { the mutations in } \\
\text { the NPHS2 } \\
\text { gene was negative }\end{array}$ & $\begin{array}{l}\text { Basiliximab } \\
\text { Cs, Tac, MMF }\end{array}$ & No & $\begin{array}{l}\text { Serum creatinine } \\
\quad 61 \mu \mathrm{mol} / \mathrm{L}\end{array}$ & 36 \\
\hline Audard V [33] & CR & 4 & $36(28-43)$ & No & $\begin{array}{l}\text { RTX D0 in } 2 \\
\text { patients and D0 } \\
\text { and D7 in } 2 \\
\text { patients }\end{array}$ & N/A & $\begin{array}{c}\text { Basiliximab/ATG } \\
\text { Cs, Tac/CsA } \\
\text { MMF }\end{array}$ & No & $100 \%$ graft survival & $25(12-54)$ \\
\hline
\end{tabular}


Table 3. Cont.

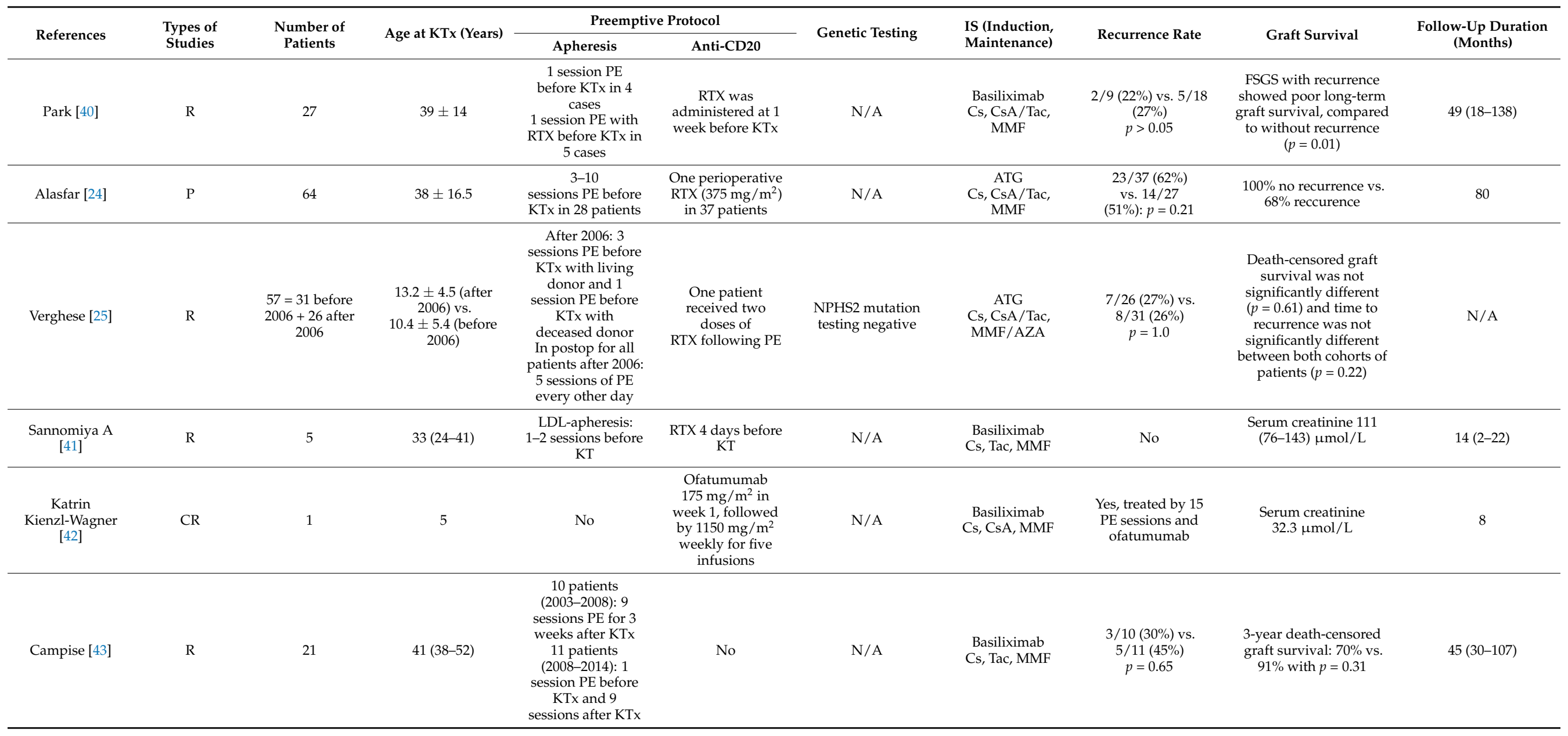


Table 3. Cont.

\begin{tabular}{|c|c|c|c|c|c|c|c|c|c|c|}
\hline \multirow{2}{*}{ References } & \multirow{2}{*}{$\begin{array}{l}\text { Types of } \\
\text { Studies }\end{array}$} & \multirow{2}{*}{$\begin{array}{c}\text { Number of } \\
\text { Patients }\end{array}$} & \multirow{2}{*}{ Age at KTx (Years) } & \multicolumn{2}{|c|}{ Preemptive Protocol } & \multirow{2}{*}{ Genetic Testing } & \multirow{2}{*}{$\begin{array}{l}\text { IS (Induction, } \\
\text { Maintenance) }\end{array}$} & \multirow{2}{*}{ Recurrence Rate } & \multirow{2}{*}{ Graft Survival } & \multirow{2}{*}{$\begin{array}{l}\text { Follow-Up Duration } \\
\text { (Months) }\end{array}$} \\
\hline & & & & Apheresis & Anti-CD20 & & & & & \\
\hline Uffing [44] & $\mathrm{R}$ & 176 & $38(29-47)$ & $\begin{array}{l}\text { Prophylactic } \\
\text { apheresis in } 22 \\
\text { patients }\end{array}$ & No & $\mathrm{N} / \mathrm{A}$ & $\begin{array}{c}\text { ATG/basiliximab/ } \\
\text { daclizumab } \\
\text { Cs, Tac/CsA, } \\
\text { MMF }\end{array}$ & $\begin{array}{l}9 / 22(41 \%) \text { vs. } \\
48 / 154(31 \%)\end{array}$ & $\begin{array}{c}\text { Graft failure occurred in } \\
18 \text { patients }(15 \%) \text { without } \\
\text { recurrence and in } 22 \\
\text { patients with recurrence } \\
(39 \%)\end{array}$ & 78 \\
\hline Auñón [45] & $\mathrm{R}$ & 34 & $32.9 \pm 15.8$ & No & $\begin{array}{c}\text { RTX, } 1 \mathrm{~g} \text { at } \\
\text { induction } \\
\text { and } 1 \mathrm{~g} \text { on day } 14 \\
\text { after } \\
\text { KT in } 12 \text { patients } \\
\text { at risk for } \\
\text { recurrence }\end{array}$ & $\begin{array}{l}\text { Patients suspected } \\
\text { of having had } \\
\text { genetic or } \\
\text { secondary forms } \\
\text { of FSGS were } \\
\text { excluded }\end{array}$ & $\begin{array}{l}\text { ATG/basiliximab } \\
\text { Cs, Tac, MMF }\end{array}$ & $\begin{array}{l}\text { 6/12 (50\%) vs. } \\
9 / 22(40.9 \%)\end{array}$ & $\begin{array}{l}53.5 \% \text { graft loss with } \\
\text { recurrence vs. } 88.5 \% \\
\text { in nonrecurrence }\end{array}$ & 71.7 \\
\hline
\end{tabular}


Plasmapheresis allowed complete or partial remission in $70 \%$ of children and $63 \%$ of adults when commenced soon after a recurrence [6]. Indeed, Trachtman et al. [46], in a literature review, reported that rituximab was associated with remission of nephrotic syndrome in $\sim 75 \%$ of patients after FSGS recurrence on a kidney allograft. Likewise, Kashgary et al. [47] published a meta-analysis that included 413 renal-transplant recipients that had relapsing primary FSGS. After a median follow-up of 19 months, they found complete or partial remission in $71 \%(95 \%$ CI $66-75 \%)$ of patients after treatment with plasma exchange. Patients treated within 2 weeks of recurrence showed a trend towards a greater likelihood of remission (OR 2.16; 95\% CI 0.93-5.01). In a study conducted by Kalliopi Vallianou et al. [19], patients with FSGS recurrence on a kidney allograft were treated by plasmapheresis and/or rituximab: this resulted in complete remission in $27 \%$ of cases and partial remission in $42.3 \%$ after an average therapy duration of $3 \pm 1.79$ and $4.4 \pm 2.25$ months, respectively.

In addition to plasmapheresis, semispecific IA has been shown to be effective at causing remission. Lionaki et al. [48] reported on 12 adult renal-transplant patients with recurrent FSGS that were treated with IA \pm rituximab: after a mean follow-up of 48.3 months, there was complete remission in $58.3 \%$ of cases, and partial remission in $41.7 \%$. Likewise, Allard et al. [49] reported complete remission in $67 \%$ and partial remission in $33 \%$ of 12 children that had undergone renal transplantation and had FSGS recurrence treated with IA sessions. After 3 months of IA treatment, two patients maintained remission without IA, and eight became IA-dependent [49].

To assess the benefit of adding rituximab to plasmapheresis to treat a FSGS relapse after kidney transplantation, Lanaret et al. [50] identified 148 adult FSGS patients that received a renal transplant between 2004 and 2018; of these, 109 received plasmapheresis (G1) and 39 received combined plasmapheresis with rituximab (G2). In the G1 group, rituximab was introduced only after failure of plasma-exchange therapy $(n=31)$; i.e., after an average of 28 days. Complete remission was achieved in $46.6 \%$ of patients, and partial remission was achieved in $33.1 \%$. Analysis of the propensity score showed no difference in the rates of complete remission and partial remission between G1 (82.6\%) and G2 (71.8\%) $(p=0.08)$. Following the addition of rituximab, $26.3 \%$ of patients had complete remission, and $31.6 \%$ had partial remission. The incidence of severe infection was similar between patients treated with or without rituximab. In multivariate analysis, infectious episodes were associated with hypogammaglobulinemia $<5 \mathrm{~g} / \mathrm{L}$.

Our study had some limitations, including its relatively small sample size, retrospective nature, heterogeneity of treatments given, and absence of genetic testing. Indeed, only one of our patients underwent genetic exploration.

\section{Conclusions}

We concluded that pretransplant prophylaxis with plasmapheresis and rituximab did not appear to reduce the risk of recurrence of primary FSGS on the graft, but potentially could allow remission in the event of recurrence, to be confirmed by randomized studies. Because recurrence can occur several years after transplantation, this justifies rigorous monitoring of patients with FSGS, more so than for other kidney-transplant recipients.

Author Contributions: Conceptualization, H.N.B. and L.R.; methodology, T.J.; software, T.J.; validation, F.T., P.M., J.N. and L.R.; formal analysis, L.E. and H.N.B.; investigation, H.N.B.; data curation, L.E. and H.N.B.; writing-original draft preparation, H.N.B.; writing—review and editing, L.R.; supervision, L.R. All authors have read and agreed to the published version of the manuscript.

Funding: This research received no external funding.

Institutional Review Board Statement: The study was conducted according to the guidelines of the Declaration of Helsinki. Ethical review and approval were waived for this study, because data collection was approved by CNIL (French national commission for data protection; approval number 1987785v0). 
Informed Consent Statement: Informed consent was obtained from all subjects involved in the study.

Data Availability Statement: Data are available upon request.

Conflicts of Interest: The authors declare no conflict of interest.

\section{References}

1. Barisoni, L.; Schnaper, H.W.; Kopp, J.B. A proposed taxonomy for the podocytopathies: A reassessment of the primary nephrotic diseases. Clin. J. Am. Soc. Nephrol. 2007, 2, 529-542. [CrossRef]

2. Haas, M.; Spargo, B.H.; Coventry, S. Increasing incidence of focal-segmental glomerulosclerosis among adult nephropathies: A 20-year renal biopsy study. Am. J. Kidney Dis. 1995, 26, 740-750. [CrossRef]

3. Korbet, S.M. Treatment of primary FSGS in adults. J. Am. Soc. Nephrol. 2012, 23, 1769-7176. [CrossRef] [PubMed]

4. Ponticelli, C.; Glassock, R.J. Posttransplant Recurrence of Primary Glomerulonephritis. Clin. J. Am. Soc. Nephrol. 2010, 5, 2363-2372. [CrossRef]

5. $\quad$ D’Agati, V.D.; Kaskel, F.J.; Falk, R.J. Focal segmental glomerulosclerosis. N. Engl. J. Med. 2011, 365, 2398-2411. [CrossRef] [PubMed]

6. Canaud, G.; Martinez, F.; Noël, L.H.; Mamzer, M.F.; Niaudet, P.; Legendre, C. Therapeutic approach to focal and segmental glomerulosclerosis recurrence in kidney transplant recipients. Transplant. Rev. 2010, 24, 21-128. [CrossRef] [PubMed]

7. Königshausen, E.; Sellin, L. Circulating Permeability Factors in Primary Focal Segmental Glomerulosclerosis: A Review of Proposed Candidates. BioMed Res. Int. 2016, 2016, 3765608. [CrossRef]

8. McCarthy, E.T.; Sharma, M.; Savin, V.J. Circulating permeability factors in idiopathic nephrotic syndrome and focal segmental glomerulosclerosis. Clin. J. Am. Soc. Nephrol. 2010, 5, 2115-2121. [CrossRef]

9. Wei, C.; El Hindi, S.; Li, J.; Fornoni, A.; Goes, N.; Sageshima, J.; Maiguel, D.; Karumanchi, S.A.; Yap, H.K.; Saleem, M.; et al. Circulating urokinase receptor as a cause of focal segmental glomerulosclerosis. Nat. Med. 2011, 17, 952-960. [CrossRef]

10. Wei, C.; Möller, C.C.; Altintas, M.; Li, J.; Schwarz, K.; Zacchigna, S.; Xie, L.; Henger, A.; Schmid, H.; Rastaldi, M.P.; et al. Modification of kidney barrier function by the urokinase receptor. Nat. Med. 2008, 14, 55-63. [CrossRef]

11. Bock, M.E.; Price, H.E.; Gallon, L.; Langman, C.B. Serum soluble urokinase-type plasminogen activator receptor levels and idiopathic FSGS in children: A single-center report. Clin. J. Am. Soc. Nephrol. 2013, 8, 1304-1311. [CrossRef]

12. Charba, D.S.; Wiggins, R.C.; Goyal, M.; Wharram, B.L.; Wiggins, J.E.; McCarthy, E.T.; Sharma, R.; Sharma, M.; Savin, V.J Antibodies to protein tyrosine phosphatase receptor type O (PTPro) increase glomerular albumin permeability (P(alb)). Am. J. Physiol. Ren. Physiol. 2009, 297, F138-F144. [CrossRef]

13. Chun, M.J.; Korbet, S.M.; Schwartz, M.M.; Lewis, E.J. Focal segmental glomerulosclerosis in nephrotic adults: Presentation, prognosis, and response to therapy of the histologic variants. J. Am. Soc. Nephrol. 2004, 15, 2169-2177. [CrossRef]

14. Doublier, S.; Zennaro, C.; Musante, L. Soluble CD40 ligand directly alters glomerular permeability and may act as a circulating permeability factor in FSGS. PLoS ONE 2017, 12, e0188045. [CrossRef]

15. Ponticelli, C. Recurrence of focal segmental glomerular sclerosis (FSGS) after renal transplantation. Nephrol. Dial. Transplant. 2010, 25, 25-31. [CrossRef]

16. Cameron, J.S.; Senguttuvan, P.; Hartley, B.; Rigden, S.P.; Chantler, C.; Koffman, D.G.; Williams, D.G.; Ogg, C.S. Focal segmental glomerulosclerosis in fifty-nine renal allografts from a single centre; analysis of risk factors for recurrence. Transplant. Proc. 1989, 21, 2117-2178. [PubMed]

17. Kaplan, A.A. Therapeutic plasma exchange: A technical and operational review. J. Clin. Apher. 2013, 28, 3-10. [CrossRef]

18. Kofman, T.; Oniszczuk, J.; Lang, P.; Grimbert, P.; Audard, V. Current insights about recurrence of glomerular diseases after renal transplantation. Nephrol. Ther. 2018, 14, 179-188. [CrossRef] [PubMed]

19. Vallianou, K.; Marinaki, S.; Skalioti, C.; Lionaki, S.; Darema, M.; Melexopoulou, C.; Boletis, I. Therapeutic Options for Recurrence of Primary Focal Segmental Glomerulonephritis (FSGS) in the Renal Allograft: Single-Center Expérience. J. Clin. Med. 2021, 10, 373. [CrossRef] [PubMed]

20. Crosson, J.T. Focal segmental glomerulosclerosis and renal transplantation. Transplant. Proc. 2007, 39, 737-743. [CrossRef] [PubMed]

21. Abbott, K.C.; Sawyers, E.S.; Oliver, J.D.; Ko, C.W.; Kirk, A.D.; Welch, P.G.; Peters, T.G.; Agodoa, L.Y. Graft loss due to recurrent focal segmental glomerulosclerosis in renal transplant recipients in the United States. Am. J. Kidney Dis. 2001, 37, 366-373. [CrossRef] [PubMed]

22. Newstead, C.G. Recurrent disease in renal transplants. Nephrol. Dial. Transplant. 2003, 18, 68-74. [CrossRef] [PubMed]

23. Maas, R.J.; Deegens, J.K.; van den Brand, J.A.; Cornelissen, E.A.; Wetzels, J.F. A retrospective study of focal segmental glomerulosclerosis: Clinical criteria can identify patients at high risk for recurrent disease after first renal transplantation. BMC Nephrol. 2013, 14, 47. [CrossRef]

24. Alasfar, S.; Matar, D.; Montgomery, R.A.; Desai, N.; Lonze, B.; Vujjini, V.; Estrella, M.M.; Dieck, J.M.; Khneizer, G.; Sever, S.; et al. Rituximab and Therapeutic Plasma Exchange in Recurrent Focal Segmental Glomerulosclerosis Postkidney Transplantation. Transplantation 2018, 102, e115-e120. [CrossRef]

25. Verghese, P.S.; Rheault, M.N.; Jackson, S.; Matas, A.J.; Chinnakotla, S.; Chavers, B. The effect of peri-transplant plasmapheresis in the prevention of recurrent FSGS. Pediatr. Transplant. 2018, 22, e13154. [CrossRef] 
26. Morello, W.; Puvinathan, S.; Puccio, G.; Ghiggeri, G.M.; Dello Strologo, L.; Peruzzi, L.; Murer, L.; Cioni, M.; Guzzo, I.; Cocchi, E.; et al. Post-transplant recurrence of steroid resistant nephrotic syndrome in children: The Italian experience. J. Nephrol. 2020, 33, 849-857. [CrossRef] [PubMed]

27. Sharma, M.; Sharma, R.; Reddy, S.R.; McCarthy, E.T.; Savin, V.J. Proteinuria after injection of human focal segmental glomerulosclerosis factor. Transplantation 2002, 73, 366-372. [CrossRef] [PubMed]

28. Ali, A.A.; Wilson, E.; Moorhead, J.F.; Amlot, P.; Abdulla, A.; Fernando, O.N.; Dorman, A.; Sweny, P. Minimal-change glomerular nephritis. Normal kidneys in an abnormal environment? Transplantation 1994, 58, 849-852.

29. Gallon, L.; Leventhal, J.; Skaro, A.; Kanwar, Y.; Alvarado, A. Resolution of recurrent focal segmental glomerulosclerosis after retransplantation. N. Engl. J. Med. 2012, 366, 1648-1649. [CrossRef]

30. Kemper, M.J.; Wolf, G.; Müller-Wiefel, D.E. Transmission of glomerular permeability factor from a mother to her child. N. Engl. J. Med. 2001, 344, 386-387. [CrossRef] [PubMed]

31. Naciri Bennani, H.; Bonzi, J.Y.; Noble, J. Immunoadsorption for Recurrent Primary Focal Segmental Glomerulosclerosis on Kidney Allografts: A Single-Center Experience and Literature Review. Blood Purif. 2020, 49, 322-333. [CrossRef] [PubMed]

32. Fornoni, A.; Sageshima, J.; Wei, C. Rituximab targets podocytes in recurrent focal segmental glomerulosclerosis. Sci. Transl. Med. 2011, 3, 85ra46. [CrossRef] [PubMed]

33. Audard, V.; Kamar, N.; Sahali, D.; Cardeau-Desangles, I.; Homs, S.; Remy, P.; Aouizerate, J.; Matignon, M.; Rostaing, L.; Lang, P.; et al. Rituximab therapy prevents focal and segmental glomerulosclerosis recurrence after a second renal transplantation. Transpl. Int. 2012, 25, e62-e66. [CrossRef] [PubMed]

34. Iguchi, Y.; Tanabe, K.; Yagisawa, T.; Fuchinoue, S.; Kawai, T.; Kawaguchi, H.; Takahashi, K.; Ito, K.; Toma, H.; Agishi, T.; et al. Plasmapheresis for prevention of recurrent focal segmental glomerulosclerosis of kidney allograft in adult recipients. Ther. Apher. 1997, 1, 191-194. [CrossRef] [PubMed]

35. Ohta, T.; Kawaguchi, H.; Hattori, M.; Komatsu, Y.; Akioka, Y.; Nagata, M.; Shiraga, H.; Ito, K.; Takahashi, K.; Ishikawa, N.; et al. Effect of pre-and postoperative plasmapheresis on posttransplant recurrence of focal segmental glomerulosclerosis in children. Transplantation 2001, 71, 628-633. [CrossRef]

36. Gohh, R.Y.; Yango, A.F.; Morrissey, P.E.; Monaco, A.P.; Gautam, A.; Sharma, M.; McCarthy, E.T.; Savin, V.J. Preemptive plasmapheresis and recurrence of FSGS in high-risk renal transplant recipients. Am. J. Transplant. 2005, 2, 2907-2912. [CrossRef] [PubMed]

37. Couloures, K.; Pepkowitz, S.H.; Goldfinger, D.; Kamil, E.S.; Puliyanda, D.P. Preventing recurrence of focal segmental glomerulosclerosis following renal transplantation: A case report. Pediatr. Transplant. 2006, 10, 962-965. [CrossRef] [PubMed]

38. Gonzalez, E.; Ettenger, R.; Rianthavorn, P.; Tsai, E.; Malekzadeh, M. Preemptive plasmapheresis and recurrence of focal segmental glomerulosclerosis in pediatric renal transplantation. Pediatr. Transplant. 2011, 15, 495-501. [CrossRef]

39. Chikamoto, H.; Hattori, M.; Kuroda, N.; Kajiho, Y.; Matsumura, H.; Fujii, H.; Ishizuka, K.; Hisano, M.; Akioka, Y.; Nozu, K.; et al. Pretransplantation combined therapy with plasmapheresis and rituximab in a second living-related kidney transplant pediatric recipient with a very high risk for focal segmental glomerulosclerosis recurrence. Pediatr. Transplant. 2012, 16, E286-E290. [CrossRef]

40. Park, H.S.; Hong, Y.; Sun, I.O.; Chung, B.H.; Kim, H.W.; Choi, B.S.; Park, C.W.; Jin, D.C.; Kim, Y.S.; Yang, C.W. Effects of pretransplant plasmapheresis and rituximab on recurrence of focal segmental glomerulosclerosis in adult renal transplant recipients. Korean J. Intern. Med. 2014, 29, 482-488. [CrossRef]

41. Sannomiya, A.; Murakami, T.; Koyama, I.; Nitta, K.; Nakajima, I.; Fuchinoue, S. Preoperative Low-Density Lipoprotein Apheresis for Preventing Recurrence of Focal Segmental Glomerulosclerosis after Kidney Transplantation. J. Transplant. 2018, 2018, 8926786. [CrossRef] [PubMed]

42. Kienzl-Wagner, K.; Rosales, A.; Scheidl, S.; Giner, T.; Bösmüller, C.; Rudnicki, M.; Oberhuber, R.; Margreiter, C.; Soleiman, A.; Öfner, D.; et al. Successful management of recurrent focal segmental glomerulosclerosis. Am. J. Transplant. 2018, 18, $2818-2822$. [CrossRef] [PubMed]

43. Campise, M.; Favi, E.; Messa, P. Clinical Outcomes of Prophylactic and Therapeutic Plasmapheresis in Adult Deceased-Donor Kidney Transplant Recipients with Primary Focal Segmental Glomerulosclerosis. Exp. Clin. Transplant. 2019, 17, 461-469. [CrossRef]

44. Uffing, A.; Pérez-Sáez, M.J.; Mazzali, M.; Manfro, R.C.; Bauer, A.C.; de Sottomaior Drumond, F.; O'Shaughnessy, M.M.; Cheng, X.S.; Chin, K.K.; Ventura, C.G.; et al. Recurrence of FSGS after Kidney Transplantation in Adults. Clin. J. Am. Soc. Nephrol. 2020, 15, 247-256. [CrossRef] [PubMed]

45. Auñón, P.; Polanco, N.; Pérez-Sáez, M.J.; Rodrigo, E.; Sancho, A.; Pascual, J.; Andrés, A.; Praga, M. Preemptive rituximab in focal and segmental glomerulosclerosis patients at risk of recurrence after kidney transplantation. Clin. Kidney J. 2021, 14, 139-148. [CrossRef]

46. Trachtman, R.; Sran, S.S.; Trachtman, H. Recurrent focal segmental glomerulosclerosis after kidney transplantation. Pediatr. Nephrol. 2015, 30, 1793-1802. [CrossRef]

47. Kashgary, A.; Sontrop, J.M.; Li, L.; Al-Jaishi, A.A.; Habibullah, Z.N.; Alsolaimani, R.; Clark, W.F. The role of plasma exchange in treating post-transplant focal segmental glomerulosclerosis: A systematic review and meta-analysis of 77 case-reports and case-series. BMC Nephrol. 2016, 17, 104. [CrossRef] 
48. Lionaki, S.; Vlachopanos, G.; Georgalis, A.; Liapis, G.; Skalioti, C.; Zavos, G.; Boletis, J.N. Individualized scheme of immunoadsorption for the recurrence of idiopathic focal segmental glomerulosclerosis in the graft: A single center experience. Ren. Fail. 2015, 37, 777-783. [CrossRef] [PubMed]

49. Allard, L.; Kwon, T.; Krid, S. Treatment by immunoadsorption for recurrent focal segmental glomerulosclerosis after paediatric kidney transplantation: A multicentre French cohort. Nephrol. Dial. Transplant. 2018, 33, 954-963. [CrossRef]

50. Lanaret, C.; Anglicheau, D.; Audard, V. Rituximab for recurrence of primary focal segmental glomerulosclerosis after kidney transplantation: Results of a nationwide study. Am. J. Transplant. 2021, 21, 3021-3030. [CrossRef] 